\title{
PENGARUH MOTIVASI BELAJAR TERHADAP PENINGKATAN PRESTASI BELAJAR SISWA PADA MATA PELAJARAN PKN SISWA KELAS VIII SMP NEGERI 2 BARAT SEMESTER GENAP TAHUN PELAJARAN 2014/2015
}

\author{
Soenarjo* \\ Siska Diana Sari ${ }^{* *}$ \\ Dwijayanto $^{* * *}$
}

\begin{abstract}
Abstrak
$\mathrm{P}$ enelitian ini bertujuan untuk mendeskripsikan pengaruh motivasi belajar terhadap peningkatan prestasi belajar PKN siswa kelas VIII SMP Negeri 2 Barat semester genaptahun pelajaran 2014/2015.Penelitian ini adalah penelitian kuantitatif.Populasinyaadalah siswa kelas VIII berjumlah 191 siswa.Penentuan sampel sebanyak 38 siswa.Teknik pengumpulan data menggunakan angket.Teknik analisis data menggunakan rumus regresi linier sederhana.Hasil penelitian menunjukkan bahwa ada pengaruh yang signifikan antara motivasi belajar terhadap peningkatan prestasi belajar. Berdasarkan hasil uji hipotesis ditemukan harga $a=39,022$ dan harga $b=0,4$, persamaan regresinya yaitu $\hat{\mathrm{Y}}=39,022+0,4 \mathrm{X}$. Hasil dari koefisien $\mathrm{b}$ menunjukkan angka positif, berarti apabila nilai atau harga $X$ pada variabel motivasi belajar naik, prestasi belajar juga akan naik. Hasil tersebut menunjukkan bahwa ada pengaruh antara motivasi belajar terhadap peningkatan prestasi belajar PKN. Koefisien korelasi $\mathrm{r}^{2}$ $=0,0693^{2}=0,0048$. Hal ini menyatakan bahwa prestasi belajar dipengaruhi oleh motivasi belajar sebesar 4,8\%, sisanya 95,2\% dipengaruhi oleh faktor lain. Hasil tersebut menunjukan bahwa ada pengaruh yang positif antara motivasi belajar terhadap peningkatan prestasi belajar siswa kelas VIII SMP Negeri 2 Barat Semester Genap Tahun Pelajaran 2014/2015.
\end{abstract}

Kata Kunci: Motivasi Belajar, Prestasi Belajar

\footnotetext{
* Dosen Prodi PPKn IKIP PGRI Madiun

** Dosen Prodi PPKn IKIP PGRI Madiun

*** Mahasiswa Prodi PPKn IKIP PGRI Madiun
} 


\section{PENDAHULUAN}

Ilmu pengetahuan dan teknologi terus berkembang di Indonesia. Hal inimerupakan dampak dari globalisasi. Tuntutan masyarakat semakin kompleks dan persainganpun semakin ketat, apalagi dalam menghadapi era globalisasi dan perdagangan bebas. Untuk itu, perlu disiapkan sumber daya manusia yang berkualitas. Salah satu upaya meningkatkan sumber daya manusia melalui jalur pendidikan.

Setiap manusia tidak lepas dari dunia pendidikan. Pada hakikatnya, pendidikan adalah usaha sadar untuk mengembangkan kepribadian, kemampuan di dalam atau di luar sekolah serta meningkatkan mutu kehidupan dan martabat manusia dalam rangka upaya mewujudkan tujuan nasional.

Berdasarkan tujuan negara dalam pembukaan UUD 1945 alinea ke-4, salah satunya adalah mencerdaskan kehidupan bangsa. Tujuan esensial pendidikan adalah mengupayakan subjek didik menjadi pribadi yang utuh dan terintegrasi. Untuk mencapai tujuan ini, tugas dan tanggung jawab siswa adalah menciptakan situasi dan kondisi yang memuat iklim yang dapat dihayati untuk memperdalam dan memperluas makna-makna esensial serta meningkatkan minat dan motivasi dari dalam dirinya guna memperoleh prestasi belajar yang baik. Berdasarkan Undang-Undang Nomor 20 tahun 2003 tentang Sistem Pendidikan Nasional bahwa Pendidikan nasional berfungsi mengembangkan kemampuan dan membentuk watak serta peradaban bangsa yang bermartabat dalam rangka mencerdaskan kehidupan bangsa, bertujuan untuk berkembangnya potensi peserta didik agar menjadi manusia yang beriman dan bertakwa kepada Tuhan Yang Maha Esa, berakhlak mulia, sehat, berilmu, cakap, kreatif, mandiri, dan menjadi warga negara yang demokratis serta bertanggung jawab. Menurut Shochib (2010: 2), Pendidikan umumnya dilaksanakan di lingkungan keluarga, sekolah, dan masyarakat. Dengan demikian, keluarga, sekolah dan masyarakat merupakan salah satu lembaga yang mengemban tugas dan tanggung jawab dalam pencapaian tujuan pendidikan umum yang salah satunya 
adalah memberikan motivasi kepada peserta didik.

Menurut Tulus Tu'u (2004: 96), motivasi adalah kekuatan yang mendorong dan menggerakkan seseorang untuk berbuat sesuatu atau bertingkah laku tertentu. Sejalan dengan hal itu, Rani Febrianti(2013: 1) berpendapat bahwa orang tua merupakan salah satu faktor yang mempengaruhi motivasi anak dalam belajar. Jadi, dapat disimpulkan bahwa pentingnya orang tua atau guru untuk memberikan motivasi kepada siswa untuk lebih memotivasi dirinya agar menjadi lebih baik, baik dalam lingkungan sekolah, keluarga maupun di lingkungan masyarakat khususnya dalam hal belajar. Pendidikan sekolah menengah pertama merupakan masa siswa mengalami transisi dari remaja sampai menjadi dewasa. Oleh karena itu, motivasi belajar yang tinggi haruslah dimiliki serta tertanam dalam diri setiap peserta didik agar tercapai tujuan pendidikan nasional guna mencetak generasi yang cakap, berilmu serta bertanggung jawab.

Motivasi belajar siswa membutuhkan keterlibatan dan tanggung jawab yang kompleks, selaras dengan pertumbuhan anak dan tuntutan zaman. Para orang tua dan guru dituntut untuk membantu anak menjadi termotivasi dalam meningkatkan prestasi belajarnya. Dengan pentingnya motivasi belajar, masa depan bangsa ada di tangan generasi muda masa kini.

Salah satu cabang pendidikan yang ada pada Sekolah Menengah Pertama adalah mata pelajaran Pendidikan Kewarganegaraan. Dalam pendidikan formal di sekolah, guru sangat berperan dalam menyampaikan pesan moral tersebut melalui mata pelajaran PKn. Guru adalah pendidik profesional dengan tugas utama mendidik, mengajar, membimbing, mengarahkan, melatih, menilai, dan mengevaluasi peserta didik pada pendidikan anak usia dini jalur pendidikan formal, pendidikan dasar, dan pendidikan menengah (Undang-Undang RI Nomor 14 tahun 2005 tentang guru dan dosen).

Proses pembelajaran PKn tidak lepas dari motivasi belajar siswa karena motivasi belajar selaras dengan materi pendidikan kewarganegaraan yang memfokuskan pada pembentukan diri yang beragam, baik dari segi 
agama, sosio-kultural, bahasa, usia, dan suku bangsa untuk menjadi warga negara Indonesia yang cerdas, terampil, dan berkarakter.

Peran atau perhatian orang tua yang sangat minim menjadikan siswa kurang termotivasi untuk belajar.Hal itulah yang menyebabkan merosotnya prestasi belajar siswa.Terdapat dua aspek yang mempengaruhi minat dan motivasi anak untuk bersekolah, yaitu aspek internal siswa dan aspek eksternal siswa.Aspek internal meliputi kemampuan, minat, motivasi, sikap, harapan, dan persepsi siswa tentang sekolah.Aspek eksternal meliputi latar belakang ekonomi orangtua, latar belakang pendidikan orang tua, persepsi orang tua tentang pendidikan, dan peran atau perhatian orang tua.

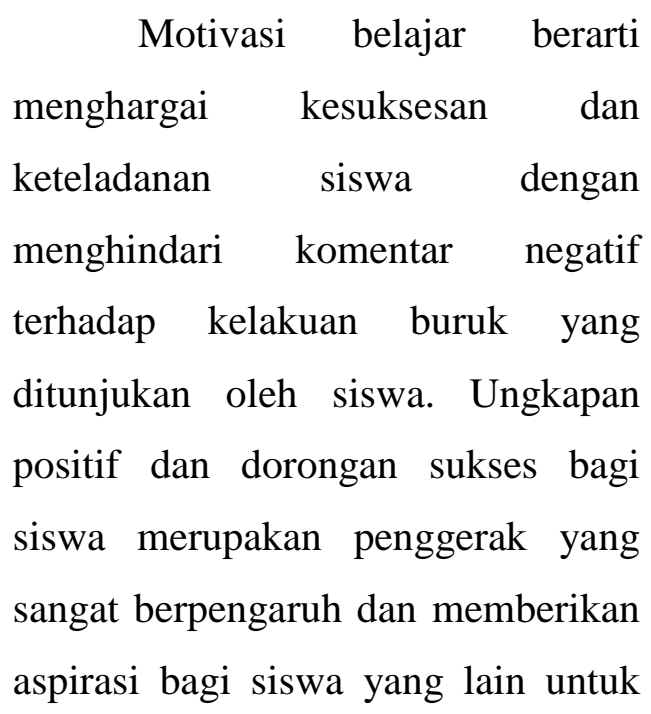

berprestasi, memberikan masukan kepada siswa dalam mengerjakan tugas mereka dengan menggunakan kata-kata positif. Usia muda sebaiknya diisi dengan melakukan kegiatan, berkreasi, menulis, mendesain, menciptakan sesuatu dan menyelesaikan suatu masalah. Jangan menjadikan siswa pasif dikelas karena dapat menurunkan minat dan rasa keingintahuan. Gunakanlah metode belajar yang aktif dengan memberikan siswa tugas berupa simulasi penyelesaian suatu masalah untuk menumbuhkan motivasi dalam belajar. Jangan berikan jawaban apabila tugas tersebut dirasa sanggup dikerjakan oleh siswa. Berdasarkan pada latar belakang di atas, dilakukanlahpenelitian yang berkaitan dengan motivasi belajar dalam pembelajaran PKn dengan judul "Pengaruh Motivasi Belajar terhadap Prestasi Belajar PKn Siswa Kelas VIII SMP Negeri 2 Barat Semester Genap Tahun Pelajaran 2014/2015".

\section{METODE PENELITIAN}

Populasi dalam penelitian ini adalah siswa kelas VIII SMP Negeri 
2 Barat berjumlah 191 siswa. Penentuan sampel dalam penelitian ini dilakukan secara random sampling. Dari proses pengambilan sampel dengan cara random diperoleh sampel sebanyak 38 siswa. Jenis data yang digunakan dalam penelitian ini adalah data kuantitatif yaitu data yang langsung diperoleh dari sumber (responden). Data dianalisis dengan menggunakan teknik Regresi Linier Sederhana menggunakan bantuan Microsoft Office Excel 2007.

\section{HASIL DAN PEMBAHASAN}

Distribusi Data Motivasi Belajar Siswa Kelas VIII SMP Negeri 2 Barat

Skor maksimum motivasi belajar siswa dari jawaban responden diperoleh skor tertinggi 57 dan skor terendah 36. Untuk mencari kelas interval adalah rentang kelas $=$ skor maksimal - skor minimal yaitu $=57$ $-36=21$ (hasil banyak interval).

Banyak interval $=1+(3,3) \log \mathrm{N}$

$=1+(3,3) \log 21$

$=1+(3,3) 1,32=5,356=5$

Panjang kelas $=$ rentang kelas : banyak kelas $=21: 5=4,2=4$
Tabel 1. Hasil Angket Mengenai

Motivasi Belajar Siswa Kelas VIII

SMPN 2 Barat Semester Genap Tahun

Pelajaran 2014/2015.

\begin{tabular}{|c|c|c|c|c|c|}
\hline No & $\begin{array}{l}\text { Nilai } \\
\text { Interval }\end{array}$ & $\mathrm{Xi}$ & Kategori & F & $\begin{array}{l}\text { Prosen- } \\
\text { tase } \%\end{array}$ \\
\hline 1 & $76-80$ & 78 & Istimewa & 1 & 2,63 \\
\hline 2 & $71-75$ & 73 & $\begin{array}{c}\text { Baik } \\
\text { Sekali }\end{array}$ & 4 & 10,52 \\
\hline 3 & $66-70$ & 68 & Baik & 11 & 28,95 \\
\hline 4 & $61-65$ & 63 & Cukup & 5 & 13,16 \\
\hline 5 & $56-60$ & 58 & Kurang & 11 & 28,95 \\
\hline 6 & $51-55$ & 53 & $\begin{array}{l}\text { Sangat } \\
\text { Kurang }\end{array}$ & 6 & 15,79 \\
\hline \multicolumn{3}{|c|}{ Jumlah } & & 38 & 100 \\
\hline
\end{tabular}

Berdasarkan penghitungan

data di atas, dapat dikatakan bahwa motivasi belajar siswa kelas VIII SMP Negeri 2 Barat semester genap tahun pelajaran 2014/2015 baik. Hal ini terbukti dari 38 siswa ada $2,63 \%$ berkategori istimewa, $\quad 10,52 \%$ berkategori baik sekali, 28,95\% berkategori baik, $13,16 \%$ berkategori cukup, 28,95\% berkategori kurang, dan $15,79 \%$ berkategori sangat kurang.

Distribusi Data Prestasi Belajar Siswa Kelas VIII SMP Negeri 2 Barat.

Skor maksimum prestasi belajar siswa dari jawaban responden diperoleh skor tertinggi 72 dan skor terendah 52. Untuk mencari kelas 
interval adalah rentang kelas $=$ skor maksimal - skor minimal yaitu $=72$ $-52=20$ (hasil banyak interval).

Banyak interval $=1+(3,3) \log \mathrm{N}$

$=1+(3,3) \log 20$

$=1+(3,3) 1,30=5,29=5$

Panjang kelas $=$ rentang kelas : banyak kelas $=20: 5=4$

Tabel 2 .Interval Kelas Hasil Angket

Mengenai prestasi belajar Siswa

Kelas VIII SMPN 2 Barat Tahun

Pelajaran 2014/2015.

\begin{tabular}{|c|c|c|c|c|c|}
\hline No & $\begin{array}{c}\text { Nilai } \\
\text { Interval }\end{array}$ & $\mathrm{Xi}$ & Kategori & $\mathrm{F}$ & $\begin{array}{c}\text { Prosen- } \\
\text { tase } \%\end{array}$ \\
\hline 1 & $72-76$ & 74 & $\begin{array}{c}\text { Baik } \\
\text { Sekali }\end{array}$ & 2 & 5,26 \\
\hline 2 & $67-71$ & 69 & Baik & 11 & 28,95 \\
\hline 3 & $62-66$ & 64 & Cukup & 4 & 10,53 \\
\hline 4 & $57-61$ & 59 & Kurang & 12 & 31,58 \\
\hline 5 & $52-56$ & 54 & $\begin{array}{c}\text { Sangat } \\
\text { Kurang }\end{array}$ & 9 & 23,68 \\
\hline \multicolumn{3}{|c|}{ Jumlah } & & 38 & 100 \\
\hline
\end{tabular}

Berdasarkan penghitungan

data di atas, dapat dikatakan bahwa prestasi belajar siswa kelas VIII SMP Negeri 2 Barat semester genap tahun pelajaran 2014/2015 adalah kurang. Hal ini terbukti dari 38 siswa ada $5,26 \%$ berkategori baik sekali, $28,95 \%$ berkategori baik, 10,53\% berkategori cukup, $31,58 \%$ berkategori kurang dan 23,68\% berkategori sangat kurang.
Tabel 3. HasilUji Reliabilitas Angket motivasi Belajar

\begin{tabular}{|c|c|c|c|}
\hline Angket & $\mathrm{r}_{\text {hitung }}$ & $\mathrm{r}_{\text {tabel }}(0.05: 38)$ & Keterangan \\
\hline $\begin{array}{c}\text { Motivasi } \\
\text { Belajar }\end{array}$ & 0.734 & 0.361 & Reliabel \\
\hline
\end{tabular}

Berdasarkan data di atas,

hasil uji reliabilitas angket motivasi belajar terhadap prestasi belajar dengan $r_{\text {tabel }}$ yaitu sebesar 0.361.Karena pada ketiga angket tesebut terlihat bahwa $r_{\text {hitung }}>r_{\text {tabel }}$, dapat disimpulkan bahwa ketiga angket tersebut adalah reliabel.

Berdasarkan penghitungan dengan menggunakan persamaan regresi ditemukan harga $a=39,022$ dan harga $\mathrm{b}=0,4$, persamaan regresinya yaitu $\hat{\mathrm{Y}}=39,022+0,4 \mathrm{X}$. Hasil dari koefisien b menunjukkan angka positif, berarti apabila nilai atau harga $\mathrm{X}$ pada variabel motivasi belajar naik, prestasi belajar juga akan naik. Hasil tersebut menunjukkan bahwa ada pengaruh antara motivasi belajar terhadap prestasi belajar PKN. Koefisien korelasi $r^{2}=0,0363^{2}=0,131$. Hal ini menyatakan bahwa prestasi belajar dipengaruhi oleh motivasi belajar sebesar $13,1 \%$, sisanya $86,9 \%$ dipengaruhi oleh faktor lain. 
KESIMPULAN

Berdasarkan perolehan interval hasil angket motivasi belajar menunjukan bahwa motivasi belajar siswa kelas VIII SMP Negeri 2 Barat Semester Genap Tahun Pelajaran 2014/2015 dari 38 siswa 2,63\% berkategori istimewa, $\quad 10,52 \%$ berkategori baik sekali, 28,95 berkategori baik, 13,16 berkategori cukup, 28,95 berkategori kurang, dan 15,79 berkategori sangat kurang. Hal ini membuktikan bahwa motivasi belajar siswa adalah cukup.

Perolehan interval prestasi belajar dari 38 siswa 5,26 berkategori baik sekali, 28,95\% berkategori baik, 10,53\% berkategori cukup, 31,58\% berkategori kurang, dan $23,68 \%$ berkategori sangat kurang. Hal ini membuktikan bahwa prestasi belajar siswa kelas VIII SMP Negeri 2 Barat Semester Genap Tahun Pelajaran 2014/2015 adalah kurang.

Ada pengaruh antara motivasi belajar dengan prestasi belajar siswa kelas VIII SMP Negeri 2 Barat Semester Genap Tahun Pelajaran 2014/2015. Hal ini dapat dibuktikan dari perolehan persamaan regresi yang menyatakan tanda positif yaitu
$\mathrm{Y}=39,022+0,4 \mathrm{X}$ yang berarti jika harga $\mathrm{X}$ naik satu satuan, harga $\mathrm{Y}$ juga ikut naik, sedangkan koefisien korelasi sebesar $0,0363^{2}=0,131$ yang menyatakan bahwa prestasi belajar dipengaruhi oleh motivasi belajar sebesar $13,1 \%$, sisanya $86,9 \%$ dipengaruhi oleh faktor lain. 


\section{DAFTAR PUSTAKA}

Abu Ahmadi. 2003. Psikologi Umum. Jakarta : Rineka Cipta.

Amira. 2012. Self Disclosure Orang Tua Mempunyai Anak Down Syndrome.

JurnalPsikologi (Online), (http://repository.gunadarma. ac.id, Diunduh 14 April 2013).

Bimo Walgito. 2010. Pengantar Psikologi Umum. Jogjakarta : Andi Offset.

Buchari Alma. 2010. Pembelajaran Studi Sosial.Bandung : Alfabeta.

Fuad Ihsan. 2010. Dasar-Dasar Kependidikan.Jakarta : Rineka Cipta.

Jalaluddin Rakhmat. 2009. Psikologi Komunikasi. Bandung :Remaja Resda Karya.

Moch.Shochib.2010. Pola Asuh Orang Tua Dalam Membantu Anak Mengembangkan Disiplin Diri. Jakarta: Rineka Cipta.

Ngainun Naim. 2012. Character Building.Jogjakarta : Ar-rutzz Media.

Ngalim Purwanto. 2006. Ilmu Pendidikan Teoretis Dan Praktis. Bandung :Remaja Rosda Karya.

Nurla Isna. 2011. Pendidikan Karakter di Sekolah. Jogjakarta : Laksana.
Oemar Hamalik. 2003. Proses Belajar Mengajar. Jakarta: PT Bumi Aksara.

Popi Sopiatin. 2011. Psikologi Belajar Dalam Perspektif Islam.Bogor:Ghalia Indonesia.

Sardiman. 2011. Interaksi Dan Motivasi Belajar Mengajar. Jakarta : RajaGrafindo Persada.

Slameto. 2010. Belajar \& FaktorFaktor yang Mempengaruhi. Jakarta: PT Rineka Cipta.

Sugihartono, Kartika Nur Fathiyah dkk. 2007. Psikologi Pendidikan. Yogyakarta: UNY Press.

Sugiyono. 2012. Metode Penelitian Kuantitatif, Kualitatif dan $R \& D$. Bandung: Alfabeta.

Suharsimi Arikunto. 2010. Prosedur Penelitian Suatu Pendekatan Praktik. Jakarta: PT Rineka Cipta.

Sumadi Suryabrata. 2012. Psikologi Pendidikan. Jakarta: Rajawali Pers.

Syaiful Bahri. 2002. Psikologi Belajar. Jakarta : Rineka Cipta.

Tulus Tu'u. 2004. Peran Disiplin Pada Perilaku Dan Prestasi Siswa. Jakarta: Grasindo.

Undang - Undang No 23 Tahun 2003 Tentang Sistem Pendidikan Nasional.

Zubaedi. 2011. Desain Pendidikan Karakter Konsepsi Dan 
Aplikasinya DalamLembaga

Pendidikan. Jakarta:

Kencana. 